Bu makaleye atıfta bulunmak için/To cite this article:

MAHFUZ, Z. (2021). Ziya Osman Saba'nın Şiirlerinde Duygu ve Düşünce Dünyası. Atatürk Üniversitesi Sosya

Bilimler Enstitüsü Dergisi, 25 (4), 1552-1572.

\title{
Ziya Osman Saba’nın Şiirlerinde Duygu ve Düşünce Dünyası
}

$$
\text { Mahfuz ZARIÇ (*) }
$$

Öz: Cumhuriyet dönemi şair ve yazarlarından Ziya Osman Saba, aynı zamanda edebiyat tarihinde adları Yedi Meşaleciler olarak anılan topluluğun bir üyesidir. Saba'nın Sebil ve Güvercinler (1943), Geçen Zaman (1947) ve Nefes Almak (1957), Cümlemiz-Bütün Şiirleri (2014) adlı şiir kitaplarında toplamda yüz elli üç şiir bulunmaktadır.

Ziya Osman Saba'nın şiirlerine yansıyan özlem ve arzular tematik açıdan hatıralar ve hayallerle ilişkilidir. Şairin duygu ve düşünce dünyasında "çocukluk ve gençlik yıllarına duyulan özlem, muhayyel belde özlemi; tabiat, şehir, ev ve aile; Allah, teslimiyet, kendini bilme; hayat, ölüm ve öte âlem" gibi konular izleklere dönüştürülmüştür. Sanat anlayışı öz-saf şiire dayanan Saba, hayata ve insanlara merhamet duygusu ve iyimserlikle yaklaşmıştır. Şiirlerinde mutlu aile tabloları çizmiştir. Sükûta ve beyaz renge şiirlerinde ayrı bir önem veren Saba, şiirlerinde yeşillikler ve denizle iç içe 'o belde'lere yer vermiştir. Şair için birer kaçıs yeri de olan o belde'ler, öte hayata geçmiş tanıdıkların, anne-baba, eş ve çocuklardan oluşan aile bireylerinin de içinde mutlulukla yer alacağı mekânlardır. Saba, ölümü kaçınılmaz bir son, ölülere kavuşturan bir köprü, yeniden diriliş durağı, Tanrı çağrısı olarak şiirleştirmiştir. Tabiata ve insanlığa karşı her zaman iyiliği salı veren Saba, II. Dünya Savaşı yıllarında kaleme alınmışs şiirlerinde ise savaş ve militarizm eleştirisinde bulunmuştur.

Anahtar Kelimeler: Ziya Osman Saba, șiir, duygu, düşünce, hatıra, hayal, hayat.

\section{The Emotion and Thought Realm in Ziya Osman Saba's Poems}

Abstract: Ziya Osman Saba, one of the poets and writers of the Republican period, is also a member of the community known in Turkish literature history as "Yedi Meşaleciler". There are a total of one hundred and fifty-three poems in Saba's poetry books called Sebil ve Güvercinler (1943), Geçen Zaman (1947) and Nefes Almak (1957), Cümlemiz-Bütün Şiirleri (2014).

The longings and desires reflected in Ziya Osman Saba's poems are thematically related to memories and dreams. The topics such as "the longing for childhood and youth, the longing for an imaginary town; nature, city, home and family; God, resignation, knowing oneself; life, death and the afterlife" are thematized in the realm of the poet's emotions and thoughts. Saba, whose artistic understanding is based on pure poetry, approaches life and people with a sense of compassion and optimism. He draws happy family pictures in his poems. Saba, who attaches special importance to silence and white color, gives place to "utopian lands' intertwined with greenery and sea in his poems. Those lands, which are also places of escape for the poet, are places, where family members consisting of parents, spouses and children who have passed away, will happily take their place. Saba poetizes the death as an inevitable end, a bridge that brings the dead together, a resurrection station, and a call from God. Saba, who always recommends

${ }^{*}$ Doç. Dr., Batman Üniversitesi Fen Edebiyat Fakültesi Türk Dili ve Edebiyatı Bölümü (e-posta: mahfuzzaric@gmail.com) (D) ORCID ID. https://orcid.org/0000-0003-0960-4807

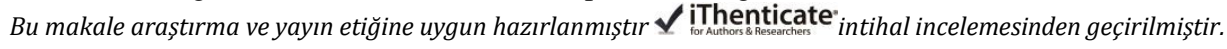


goodness towards nature and humanity, criticizes warfare and militarism in his poems written during the World War II.

Keywords: Ziya Osman Saba, poem, emotion, thought, memory, dream, life.

Makale Geliș Tarihi: 14.07.2021

Makale Kabul Tarihi: 21.12.2021

DOI: 10.53487/ataunisosbil.971231

\section{Giriş}

1910'da İstanbul'da bir asker çocuğu olarak dünyaya gelen Ziya Osman Saba, ilk düzyazısını Birinci Dünya Savaşı sonrası Mütareke yıllarında, İspanyol nezlesinden kaybettiği annesi hakkındadır. İlk şiiri “Sönen Gözler” on yedi yaşında Servet-i Fünûn-Uyanış dergisinde yayımlanan Saba, altı arkadaşı ile birlikte Meşale (1928) adlı ortak kitabı yayımlamakla, edebiyat tarihindeki yerini Yedi Meşaleciler (1928) topluluğu içinde yer almıştır. Meşale, Milliyet, İçtihat, Varlık, Büyük Doğu, Yücel gibi yayın organlarında yazıları yayımlanan Saba, topluluğun şiir anlayışına uygun eserler vermeyi, sanat hayatı boyunca sürdürmüştür.

İki evlilik yaşayan Saba, hukuk eğitimi almış (1936); muhasebecilik, bankacılık, düzeltmenlik, editörlük gibi meslekler icra etmiştir. Saba'nın ilk şiir kitabı Sebil ve Güvercinler 1943 yılında, Geçen Zaman 1947'de yayımlanmıştır. Şairin ölümünden sonra Nefes Almak, Cümlemiz-Bütün Şiirleri ${ }^{1}$ adlı şiir kitabı yayımlanmıştır. Onun şiirleriyle ortak temler etrafında şekillenmiş öyküleri ise Mesut Insanlar Fotoğrafhanesi (1952) ve Değişen İstanbul (1959) adlarıyla yayımlanmıştır. Goncourt Kardeşler'in Germinie Lacerteux romanını da Türkçeye çevirmiş olan Saba, 1957'de hayata veda etmiştir. Şairin Eyüp Mezarlı̆̆ı'ndaki kabrinin yeri bilinmemektedir (Kurdakul, 1973: 237-468; Kurdakul, 2000: 164; Uysal, 2004: 263, 264, 267; Yardim, 2006: 315, 316-320).

Saba, kendi şiir sanatına dair düşüncelerini ifade ettiği bir söyleşide, şiir yazmak benim için bir eğlence olmak şöyle dursun bu (mutlaka bir sanat eseri vermek) benim için bir ihtiyaç, bir zaruret, âdeta yaşamamın sebep ve hikmetidir demiş; yazma gayesini açıklarken ölüm karşısında bile en büyük üzüntüsünün "sevdiklerine bırakmak üzere yeterince eser verememesi" olacağını vurgulamıştır (Fahir Önger'den akt. Miyasoğlu, 1999: 76). Ziya Osman, Cevdet Kudret'e yazdığı bir mektubunda Kudret'in şiir yolculuğunda Halk şiiri çizgisinde yol almasından yakınmış, şiirlerine Yunus Emre havası vermek isteyişini eleştirmiştir. Cevdet Kudret'e "kendi janrında" yazmaya devam etmesini tavsiye etmiştir. Hece ölçülü şiirlerinden sonra serbest şiirler kaleme almış olan Saba, sol heyecanlar ve israrlarla yazılmış şiirlerin şiiri mahdut, dar bir çerçeve içine soktuğundan yakındığı bir başka mektubunda ise ideal şiir dili konusundaki görüşlerini dile getirmiştir. Ona göre Yunus Emre, bugün şiir yazmaya başlayacak olsa eski asırlardaki lisanı

${ }^{1}$ Şairin şiirlerindeki duygular ve düşüncelere odaklanılan bu inceleme yazısında, Saba'nın içinde yüz elli üç şiir bulunan Cümlemiz-Bütün Şiirler adlı eseri, "C" kısaltması ile gösterilecektir. 
kullanmayacak, şiirlerini bugünkü tekâmül etmiş şiir lisanıyla yazacaktır (Kudret, İnci, 1995: 34-38).

Merhamet, sevgi, yaşama sevinci; hatıralar, özlemler, arzular; kaçış, 'o belde' ve sükûtu şiirlerinde izleklere dönüştüren Ziya Osman, sanatının ve garip şiirinin, okurları için olduğunu söyler; duydukların duyan okurlara seslenir (C: 166). Saba, insanlara iyiliği ve iyi duyguları aşılamak isteyen bir şairdir. "Yokuş" başlıklı şiirinde "Kendimden söz etmek istiyorum, /.../ İçimi dökmek istiyorum birinize," diyen Saba, dıştan farklı görünseler de biletçi, polis, herkesin içten bir olduğunu hatırlatır. (C: 164, 165) Saba, "Alışmak" adlı şiirinde de zıtlıkları kendilerinde bir arada barındıran insanları temsilen "Sefaya, cefaya, ölene, doğana / Kuş cıvıltısına, insan hıçkırığına." alıştığını söyler. (C: 153).

Sanatı hakkında bugüne kadar pek çok kitap, tez ${ }^{2}$ ve inceleme yazısı kaleme alınmış olan Ziya Osman Saba'nın şiirlerinde anlam, ses ve kelime gibi unsurların seçimiyle, konuyu ilk sıraya koyduğu belirtilmiştir (Yüksel, 2006: 29). Şiirleriyle çocukluğuna ve İstanbul'a imrendiren, duyarlı bir şair olarak nitelenen Saba, Cahit Sitkı Tarancı ile dostluk kurduğu Galatasaray Lisesinde iken Fransızcasından okuduğu Fransız şairlerine hayranlık duymaya başlamışıı (Yardım, 2006: 316, 317). Onun şiirini etkileyen yabancı kaynaklar konusunda, kendisine dayandırılarak Baudelaire, Mallarme, Regnier, Rimbaud gibi Fransız şairlerinin ve yaptı̆̆ 1 çevirilerin etkisinde kaldığı söylenmiştir. Saba'nın şiir dilinin sürekli olarak saflaşma eğiliminde olduğu; şiirlerinde, insan sevgisi dolu bir kalbin terennümünü görüldüğ̈̈; onun şiirinde nesnel olanın, içselleşerek kendi metafiziğini yarattığı belirtilmiş; şiirlerinde özel bir şiir dili yaratmayı değil de konuşma dilinin şiirselliğini bulmayı amaçladığı vurgulanmıştır (Korkmaz; Özcan, 2005: 241; Bek, 2004: 65).

Şükran Kurdakul'a göre ise Saba; Ahmet Muhip Dranas, Cahit Sttkı Taranc1, Fazıl Hüsnü Dağlarca kuşağının en içe dönük şairi olarak görülmüş, on dokuzuncu asır edebiyat anlayışı çerçevesinde kalmıştır. $\mathrm{O}$, şiirlerinde başarılı bir teknik sergilemişse de sonuçta kendisinden sonra gelen kuşaklara yeni yollar açacak güçlü bir şiir kuramamıştır (Kurdakul, 1973: 328).

Şairlik yönü ön plana çıkan Saba'nın öyküleri bir tür mutluluk arayışı; çocukluk ve olgunluk yıllarından izler taşıyan, o günlerin tadının arandığı metinler; şiirleriyle ortak imgeler barındıran, anlatının sonunda içinde bulunulan zamana geri dönülen, açık uçlu

${ }^{2}$ Yüksek Öğretim Kurulu Tez Merkezi sistemindeki çalışmalarda Saba'nın şiirlerindeki konular "Melankolik ve Karamsar Ruh Hâli, Aşk, Zaman, Ölüm, Aile Hayatı ve Ev, Mutluluk ve Yaşam Sevinci, $\quad$ Deniz ve İstanbul, İnsan, Çocuk, İman” (Kırc1, 1991); "Geçmişe Özlem: Çocukluk, Gençlik ve Okul Hayat1, Özlem ve Ölüm, Uzak Diyarlara Özlem ve Öte Duygusu, Aile Hayatı ve Mutluluk, Karamsarlık, Hayat ve Toplum” (Uygur, 2005); "ev-güzellik, ev modernite-gelenek ilişkisi, sığınak-mutluluk kaynağ ev" (Demirel, 2007); "Ev ve Aile, Gelecek Hayali, Ölü/Tabiat, Tanrı, Zaman ve Diğer Temalar" (Akbulut, 2008); "Şehir (İstanbul), Tabiat; Şehir ve Mimari, Musiki, İnsan, Değişim, Sorunlar, Yalnızlık, Yabancılaşma..." (Tuna, 2020) başlıkları altında incelenmiştir. 
ve belli durumların anlatıldığı öyküler olarak nitelenmiştir (Kürüm, 2018: 76; Sakallı, 2011: 167; Uygur, 2005: 128, 129). Onun öykülerinde tür endişesinin ikinci planda tutulduğu, değişen İstanbul'un çehresini otobiyografik olarak yansitıldığg; öykülerinin tıpkı şiirleri gibi incelikli, dost yürekli ve sevecen bir atmosfere sahip metinler olduğu da kaydedilmiştir (Miyasoğlu, 1999: 11; İleri, 1992: 16).

\section{II. Şiirlerinde Duygu Dünyası}

\section{A. Merhamet, Sevgi ve Yaşama Sevinci}

Şiir incelemelerinde temelde şekil ve içerik unsurları olmak üzere iki ana başlık altında çözümlemeler yapılmaktadır. Dil-üslup ve ahenk özellikleri de ayrıca ele alınabildiği gibi söz konusu başlıkların altında da değerlendirilebilmektedir. Şiirde içerik incelemesinde temel hedef şiirdeki olay, konu, duygu ve izlekleri belirlemektir.

Konu ve izlek/tema kavramları, günlük dilde çoğu kez aynı manada kullanılsa da şiir incelemelerinde hususi manalarıyla kullanılmaktadır. Konu terimiyle şiirin düzey yapısında yer alan unsurlar, genel ve evrensel nitelikli nesnel olgular, durumlar, olaylar ve meseleler kastedilirken; izlek terimiyle konunun şaire özgü bir biçimde görünüşü, yorumlanışı ve değerlendirilişi, şairin konuya öznel bakış açısı kastedilmektedir. İçerik incelemesinde duygular ve düşünceler de tematik başlıkların yanı sıra "yumuşak, kötümser ve heyecan”, "doğal, hikemî, mistik, ideolojik, öğretici” gibi başlıklar altında incelenebilmektedir (Çetin, 2009: 13-38, 5478).

Şiir incelemelerinde dikkat çeken durumlardan birisi de ana izleklere odaklanılıp şiirlerin tematik açıdan sınırlanması, şiirlerdeki tali konu ve izleklerin ikinci plana atılmasıdır. Bu sayılan çekincelerle tematik açıdan genel bir tasnife tabi tutulduğunda, Ziya Osman Saba'nın duygu ve düşünce dünyasını yansıtacak şekilde şiirlerinde izleğe dönüştürülen belli başlı konuların "merhamet, yaşama sevinci; hatıralar, çocukluk ve gençlik yıllarına duyulan özlemler, bir diyara/mekâna duyulan hasret, kaçış, sükût; ev, aile tutkusu, sevgi ve aşk; Allah, teslimiyet, hayat-ölüm, yokluk ve fena arzusu; tabiat, canlılar, tabiat ve İstanbul” olduğu söylenebilir. Saba'nın şiir dünyasında kendilerine hususi bir yer bulmuş iki şahsiyet ise Mustafa Kemal Atatürk ve Cahit Sıtkı Tarancı'dır.

1923-1940 Dönemi Türk şiirini “Eskiler, Memleket edebiyatı, Öz şiir” olmak üzere üç gruba ayıran İnci Enginün, Ziya Osman Saba'nın içinde bulunduğu Yedi Meşaleciler'i öz şiir grubuna dâhil eder. Saba'nın, şiirlerinde “ev içi” konusuyla Behçet Necatigil'e örnek olduğunu vurgular. Şairin Yunus Emre ve Mevlana'dan aldığ1 geleneğin insan sevgisi cephesini modern çağa taşıdığını belirtir (Enginün, 2001: 71).

Yaşar Nabi'ye ithaf edilen "İyilik” şiirinin o belde'sinde dere, şaire geçen ömrünü söyler. Sükûn, çamlardan çimenlere dökülür. Şair, içinin Tanrı'nın eseri olduğunu fark eder. Gözleriyle ağaçları, dereyi, bütün tabiatı okşar. Şair, ruhun vücutta ürperişinde, beyaz koyunda, gülümseyen yüzde, baharda, mavi göklerde, yemyeşil sükûnda hep iyiliği bulur (C: 19). 
Şairin, mazi ve âtinin yanı sıra içinde bulunulan hâlden memnun olduğu pek çok mısrası da bulunmaktadır. "Bu Sakin Öğle Vakti" başlıklı şiirinde mevsim taze, gün 1lıktır. Ezan sesi, beyaz minareden düşmektedir. Bir saatin vuruşu, çocukların koşusu, kuşların dem çekişi, bütün bir tabiat ona sonsuz iyilikten bahsetmektedir. Kendinden hoşnut ve razı olan şair, "Yalnız" başlıklı şiirde kendine "Kalbim, sen çocuk kaldın, tanımadın kini” diye seslenir. Ölüm sonrasında bile kalbi ile yalnız kalacağını, hayallere onunla birlikte yalnız dalacağını belirtir (C: 54,86$)$.

Saba, "Doğacak Çocuklardan" başlıklı şiirde genç evlilere, delikanlılara, göklere ovalara... "Önümüz bahar," diye seslenir. Umut şairi Saba için "Sabahın Dördü” demek aydınlığa kavuşmak demektir. Mutluluk, mazideki şair beninin en belirgin ruh hâlidir. "Ben de şu parkın sıralarında oturdum / Ümid ettim, hayal kurdum..." diyen Saba, mektep yıllarındaki siyah göğüslüğünü, sevinçle dolup taşan gönlünü, akıp giden günleri, üstüne titreyen annesini, kendisiyle iftihar eden babasını hatırlar. "Hayat Cümbüşüu" şiirinde gökyüzü, altında her saadete yer vermektedir (C: $32,43,49,74)$.

Merhamet duygusu, Cennet özlemi şiirlerinden biri olan "Kavuşmalar"da zıtlıklar eşliğinde ele alınır. Korku dolu gecenin tertemiz seherine, kış içindeki yılın umulmaz baharına erişilmiştir. Her gönül, özlediği yarına çıkmış gibidir. Bu manzaradaki Cennet, şairin dünyasında İlahî merhametin diyarı demektir. Semada bir ak bulutun tasvir edildiği "Kavuşmalar"da özlenen diyarda "Sakin gülümsemede[dir] her insan diğerine."; "Bütün hastalar iyi[dir], ölüler[in]... hepsi de sağ[dır]! / Her anne evlâdını basmış[tır] artık bağrına.". Havf ve recâ gelgitleri son bulmuştur. "Korku dolu gece"den çıkılmıştır. Merhamet duygusu pekiştirmek için, Tanrı'ya da seslenen şair, çocukken kafesinden azat ettiği kuşa, "Eriştin mi, nihayet cennet kapılarına?" diye sorar. Şair "Attıkça her adımı dümdüz oluyor yokuş." demekle de kolaylıklar barındıran iyilik yolunu salık verir (C: 61). Şair, "merhamet" duygusunu "Sebil ve Güvercinler"de anlam değeri yüksek iki unsur üzerinden işler. Konusu "aile hayatı ve mutluluk; milli duygular ve saflık" olarak belirlenmiş "Sebil ve Güvercinler"de güvercinler ve sebiller ön plana çıkarılmıştır. Şair, dikkatleri ise hitaplarla seslendiği ve trajediye sebep olarak gösterdiği merhametsiz, duyarsız insanlara çekmiştir.

Sebil, insanların veya hayvanların su ihtiyacını gideren geleneksel kültürel-mimarî yapılardır. Sebiller yolda olana, yolda kalana hayatî bir ihtiyaç olan suyu sağlar. Kökeni itibariyle yol manasına gelen, hayrat ve su manalarını da yüklenmiş olan sebiller, aynı zamanda sürekliliğ̈i ve arınmayı da çağrıştırır. Medeniyet göstergeleri olan sebiller, karşılık beklemeden, yaptığ 1 iyiliğin gözetleyicisi olmadan yapılan iyiliklerin göstergesidir. Sebillerin yapı malzemelerinden olan mermer "saflık, uzun ömürlülük, temizlik, güzellik, asalet" gibi birçok mana içerir. Bu şiirdeki sebil ise susuzdur ve su bulamayan güvercinler çekip gitmiştir. "Mermer basamaklarda uçuşur beyaz tüyler." denilerek güvercinlerin ölümü de çağrıştırılır. Şiirde insan türü de "Bırak... gözyaşı sun... ; Ürkmeden su içsinler yavaş̧̧a susun, susun" öğütleriyle diğer canlılara merhamete davet edilir (C: 62).

Sebillerin tamamlayıcısı durumundaki güvercinler, bu şiirde hem yolcudurlar hem de uykuya hasrettirler. Ruhları tutuşmuş güvercinler aynı zamanda açtırlar ve "En son 
şarkılarını dağıtarak rüzgâra, beyaz boyunlarını uzatırlar taslara...", "bir damla suya hasret giderler.".

Naif güvercinler -hele beyaz renkle anılınca- en ürkek, en saf, en temiz canlılar olarak zihinlere nakşolurlar. Anadolu'da onları, çocukları onlara gelebilecek zararlardan uzak tutmak üzere, güvercin beslemek uğursuzluk getirir, şeklinde bir inanç bile geliştirilmiştir. Çocuklar; güvercinlerin yumurtalarına ellemeyin, ellerseniz yumurtaları bozulur, karıncalara yem olur denilerek, merhamet eğitimi ile bu savunmasız canlıların yuvalarından uzak tutulmuştur.

Susuz sebil ve uçuşan beyaz tüyler (ölü güvercinler) aracılığıyla, merhametsizliğin nelere yol açacağı gösterilir. "Bırak, susun, sun” gibi emir kipli yüklemler de hem sorumluları hem de yapılması gerekenleri işaret eder. Acıma duygusunu pekiştirmek için mezarlık ağacı olarak da bilinen selviler, sahneyi tamamlar. Ölümü, yalnızlığı, rüzgârla hasbıhâli hatırlatan selviler, bomboş sebilin yegâne arkadaşları durumundadır. Selviler, bomboş sebilden bir şey sorarken rüzgâr, uzayan dem çekişleri hatırlatır. Kulaklarda, "hû!" çeken güvercinlerin sesi yerine rüzgârın "En son şarkılarını dağıtarak" esen "vuu!" sesi belirir (C: 62).

"İnsan" şiirinde merhamet duygusu eşliğinde insanın sıcaklığı terennüm edilir. Şair için, onun etrafını sarmış insanlar, tıpış tıpış çocuklar, sekmekte olan genç kızlar, cıvıl cıvıl kuşlar başlı başına birer mutluluk kaynağıdır. Bu mutluluk tablosunda aile bireylerinin birbirinden ayrısı gayrısı kalmamıştır. "Perdeler inmiş gece... kat kat dolmuş", sığınak evler sıcacıktır. Şair "insanı” komşusu, hemşerisi, yurttaşı, din kardeşiyle; onu sevilir ve sıcak kılan acıma ve dayanışma yönleriyle izleğe dönüştürür. Şair hasta düşse yatağının başucunda, elini bir dostun avucunda bulmaktadır. Nabzını tutmuş doktoru, ona, ne de güzel acımaktadır. (C: 158).

İnsanlar için evlerinden içeriye rüzgâr, soğuk, karanlık girmesin, dileğinde bulunan şair, dalların "iç rahatlığı, gönül huzuru" içinde yeşerdiğini, mevsimin bahara erdiğini görmeyi diler (C: 162).

Ziya Osman Saba, "Nişanlılık" başlıklı şiirinde beyaz, sevimli, sükûnetli; umut ve sevgi dolu hatıralarında gezintiye çıkar. Dükkânlarda satıcılar güler yüzlüdür. Ağaçlar, O sakin sabahlarda, dinmiş rüzgârı dinler gibidir. İyi komşularla dolu mahallede, nişanlı çifti uzaktan tanıyan her yolcu, hâlden anlamaktadır. Parmaklardaki nişan yüzükleri, sanki yepyeni ve tertemiz bir hayatın altın ışıklarıdır (C: 87, 88). Geleceğe ümitle bakan şair, sevgili için de "Günlerimiz olacak, / Mesut, bahtiyar." vaadinde bulunur. "İnsanlar, hepinizi seviyorum! // "Ölüler! Özlemez olur muyum dünyanızı," diyen şairin sevgisi ve duyarlı̆̆ı, sadece dirileri değil ölüleri de kapsar (C: 97, 103).

"Nefes Almak" şiirinde yaşama sevincini dişa vuran; bütün sevdiklerini, her şeyi, her kesi mukaddes gören şair, "havayı bağrında duymak; ufuklara karşı maviliği koklar gibi, rüzgârı öper gibi, ana sütü emer gibi, kana kana, doya doya nefes almak" istemektedir. Rüzgârın her vakit esmeyeceğini düşünen şair, kendisine ve okurlarına “Çek ciğerlerine, bir nefes daha çek," nasihatinde bulunur (C: 111, 112, 132). 
“Kim bilir kaç günü kaldı / Ömrümüzün” diyen şairin yaşama sevinci, bazı şiirlerde yerini kalbiyle/gönlüyle yüzleşmeye ve ölüm endişesine bırakır (C: 140).

1927 tarihli "Kan...” şiirinde kalb’e "ey kanlı et parçası!”, "Neden bu vahşi kinin, nedir bu ilk 1stırap" diye seslenen şair, ruhundaki bitmeyen hırstan; azap, ölüm ve kandan yakınır. Gönül, "Kurbağalar" şiirinde kemikten kafesinde hasretle dile gelen mahpus bir kurbağaya benzetilir. Şairin birden boşanan gönlü "Dağ Üstünde Manastır" şiirinde "Yellerin boğazına zincir vurduğu günde" rüzgâr gibi inler. Şair, "Sevilen bir ölüyü bekler gibi her gece, / Kaskatı toprakları eğilip" dinleyen kalbine, yılanlar gibi ezilmemesi için "1şıkla parlayan bir cihan" olan "toprağın en dibine" girmesini salık verir. Sıcak gözyaşlarıyla ıslattığı gönlünü bir başka şiirde ise yarasalara sunar. Onlara “giyiniz, gülünüz” diye seslenir (C: 170, 171, 174, 177, 185).

\section{B. Hatıralar, Özlemler ve Arzular}

Orhan Okay'a göre 1910 sonrası Türk edebiyatında aile tema ve konuları çerçevesinde en güzel şiirleri Saba yazmıştır. Onun şiirlerinin hemen hepsi iddiasız, ihtirassız, yumuşak ve sevgi temeline dayanan, hatıra, arayış ve özlem duygularının dile getirildiği şiirlerdir (Okay, 2005: 250, 251).

Ziya Osman, diğer pek çok şiirinde olduğu gibi “Geçen Zaman” adlı şiirinde de âdeta hatıraların yükü altında adeta ezilir. Mazi özlemi içinde, eski gecelere, sevdikleriyle dolu odalara, çocukluğuna ve ilk gençliğine sığınır. Hatıralara, onu terk etmemeleri ve kendisini yalnız bırakıp uzaklaşmamaları için yalvarır (C: 17).

Ziya Osman'ın altın yıllarında "rahatlatan bir kapı sesi, bayram sabahını getiren güneş, şairden uzaklaşan günler, ahengine doyulmayan ırmak" yer almaktadır. O yıllar, onun için öylesine mutluluk kaynağıdır ki çocuk dizlerindeki yaralara bile şair, "Açılın, açılın tekrar" diye seslenir. İlk şiirini, ilk arkadaşını, ilk sevgisini, sevgilisini ilk öptüğü günü özlemle anan şair, her şeyi bırakıp bir yerlere gitmekten korkmaktadır. Bir daha o günleri hatırlayamamaktan, unutmaktan endişe duymaktadır. Ziya Osman'a göre bizler, “Şu yerle şu gökyüzü / Arasında geçen ömrümüzü” hatırlamadan edemeyiz ve "Gençlik aşk1, sevinci daha dünkü ümidi..." olan hatıralar, gün gelir "bir acı olur.” (C: 129, 139).

Şair, "Beraber" adlı şiirde, içinde akşam eve dönmenin sevinciyle, ümit dolu seherlerde, sevdiğiyle beraber, tenha kır yollarında gezmeyi hayal eder. "Nasıl Anmazsın"da şair, çarşının gürültüsü gittikçe artarken, [evlerde] odalar kararırken indirilen perdeleri, yeşil abajurlu lambayı, küçük sobaları; sevgilinin beyaz elbiseler giydiği zamanları, sevgilinin o vakitlerde yüzünün pembeliğini, saçlarının örgüsünü; kış ve yaz türküsüne bedel ömürleri hatırlar (C: 30, 33).

“Adak" şiirinde hatırlanan kişi, şaire Aşk adlı bir evliyanın yattığı yeri gösteren, mezarının dört başını birlikte tavaf ettikleri, kırık yosunlaşmış mezar taşını öptükleri, ömürlerini kandilsiz türbesine birlikte adadıkları bir sevilendir (C: 180).

1940’tan sonra şekilsel olarak serbest şiire yönelen Saba'nın şiirinde başlıklar ve içerik arasında uyuma dikkat çekilmiş; bu dönemdeki şiirlerinde iyimserlik, mutluluk, umut duyguları eşliğinde çocukluğa ve geçmişe özleme ağırlık verdiği belirtilmiştir 
(Ünlü, Özcan: 244, 245). Saba’nın hatıralara özlemlerin eşlik ettiği şiirlerinden birisi "Bir Oda, Bir Saat Sesi”" adlı şiiridir. Bu şiirde, şairin bakışları, eski sessiz ve güzel günlerin yaşandığı maziye döner. Saat sesi, şaire kime ait olduğu belirtilmeyen bir seccadeyi, tespih ve başörtüsünü; her çiçeği ıslanmış bahçeleri hatırlatır. Şairin bu şiirde ayrı bir özlemle hatırladığı kişi ise, geldiği kapının çalınmasıyla belli olan baba figürüdür (C: 29).

"Nasıl Anmazsın”da şairin “Bir gün ver bana Tanrım, / Tâ çocukluğumdan kalmış..." yakarış1; dalda bülbülün, gökte beyaz bulutun, 1lık uzayan yaz günlerinin, beyaz bir âlem olan kışın özlemi ile doludur. "Sebil ve Güvercinler"de de geçmiş "Şimdi bomboş sebilden selviler bir şey sorar, / Hatırlatır uzayan dem çekişleri, rüzgâr." mısralarıyla özlemle anılır (C: 33, 62).

"Bahar Beklerken Yazılmış Şiir”de yalnız mesut günleri taşıyacak bir baharın, bir sabah vakti görülecek yeşil tomurcukların, bir saadet içinde sessiz otlayan koyunların özlemi dile getirilir. "Yağmurlu Bir Günde", anne ve çocukluk yılları ile özdeşleştirilen sükûnete, güvene ve huzura duyulan özlem dile getirilir. Şiirde çizilen manzarada, güvenle yağmurun yağışını camda seyretmek, üşümemek, kulağına fisıldanan sükûnetli bir ses, doğduğu ev ve anne dizindeki uyku vardır. Şiirde "Beni götürseydiler doğduğum eve kadar. / O evin taşlığında sevinçten ağlasaydım.” mısralarıyla dile getirilen maziyi, insanları ve mekânlarıyla özel kılan yön sağladığı güven duygusudur. "Benim işte kalmamış önümde bir sevincim" diyen şair, yaşadığ 1 zamandan ise ölümü arzulayacak kadar mustariptir (C: 20, 67).

“Bir Sokakta Giderken"in asıl konusu geçmişe özlemdir. Hatıralar ve hayaller arasında gidip gelen şair, yaşadığı zamandan hareketle, yürüdüğü bir sokakta hem mutlu geçmişini hatırlar hem de arzuladığı diyarı hayalinde canlandırır. Bu şiirde geçmişi güzel kılan unsurlar "kalbe aşina insanlar, mektepte vaktiyle okunan şarkı, iyi olan her şey ve herkesin bahtiyar oluşu, büyükbabası ve çocukluk arkadaşı sarı benekli kedi”dir. Şiirdeki "Bütün günahlarımı affetmiş sanki Tanrım, / Duyuyorum kalbimde duyulmamış tadılmamış sevgiyi. / Ah, sade koşmak, koşmak istiyorum içimden: / Aradığım diyara bu yol çıkacak gibi." (C: 24) mısraları, tasavvuftaki "havf ve recâ" kavramlarını da hatıra getirir. Günahının bilincinde olmak, korkuyu; affedilmek ihtimali ise umudu besler. Gelgitlerden ibaret olan bu dünya hayatı da bir açıdan bu iki duygu arasındaki yaşanmışlıklardır, denge sürecidir.

"Sizleri Görüyorum”da ev, sevilenler ve aile bireyleri tabiatla birlikte "Sizler rüya mıydınız? Sizler yaşadınız mı?” denilerek özlemle anılır. Şair, adeta her bir şiiriyle, geçmişinin mutlu manzaralarını oluşturan imajların dökümünü yapar. Bu şiirde geçmişi güzel kılan hususlar "çamlı bahçe, çitlenbikler, gölgesinde oynanan dost badem; dallardan, 1lık, iniveren akşamlar; evine dönen baba, camda bekleyen anne, yerde kurt, gökte yıldız ve ev"dir. Şair, bu şiirde anlatımını daha etkili kılabilmek için soru sorma ve benzetme sanatlarından yararlanır. Bu şiirde dikkat çeken bir nokta da "anne, baba, gölge..." gibi varlıkların nihayetinde birer liman, birer sığınak olmalarıdır (C: 76). 
"İyi İnsanlar” şiirinin konusu da çocukluk özlemidir. Bu şiirde çocukluk yıllarını önemli kılan ise barındırdıkları değerlerdir. Şairin "göreceğim geldi" dediği insanlar, her şeyden önce "iyi insanlar!"dır. Denizle anılan hür gemicilerdir. Yollarla anılan şen şarkıcılardır. "Masal şehzadeleri, tarihte kahramanlar... / Toprak altındakiler”dir. Nur yüzlü büyükbabadır. Bir genç zabit olan babadır, annedir. İhtiyar hocasıdır, sınıf arkadaşlarıdır. En nihayet kendisinin çocuk kalbidir. İyi ve temiz olmak, hem şairin hayattaki özlenenlerinin hem de çocukluğunun hayal dünyasını süsleyenlerin ortak noktasıdır. O insanları özlenir ve değerli kılan, sahip oldukları saflıktır (C: 100).

"Yaşadım, Artık Bitti”de özlenenler, "hepsi de gitmiş” olanlardır, onu hep kucağına almış büyükbabasıdır. Karyolasının başında kendisine masallar anlatmış dadısıdır. İlk defa elini tuttuğu sevgilisidir. "O günleri yaşamak istiyorum," diyen şair, maziyi anmakla, içerisinin kanadığını da belirtir (C: 107).

Maziye döndüğünde hep anne-baba, eş-dost simalarıyla karşılaşan şair, âtiye yöneldiğinde de aynı figürleri gözünde canlandırır. "Şu fakir mahallede bir göz evim olsayd1," diyen Saba, kendisiyle yolda arkadaşlık edecek bir ihtiyar komşu, kendisi çalmadan kapıyı açıverecek bir eş, boynuna atılarak "Baba!" diyecek bir çocuk arzular. "Yetişir" adlı şiirinde, bir eve misafir gitmeyi, kahveyi muhatabının pişirmesini ve taze doldurulmuş sürahiden kendisine bir bardak su vermesini diler (C: 40, 41).

Şairin işitmek, görmek istediği; "ufkun arkasında", "sonsuz bahar havasında" kuşların ötüşmesi, bir narın çatlayarak düşmesidir. Şairin arzuladığı "Sahil bilmeyen köpük. / Keşfedilmemiş ada. / Dalında sarkan yemiş. Henüz ayak değmemiş / Uzun çayırlarda Tozpembe açan çiçek.”tir. Anne misali sığınılacak bir kadını çağrıştıran bir "Etek"tir. Bir kadının dizlerindeki tadılmamış uykudur. O kadına, bir çocuk gibi inanmaktır. Her şeyi ondan beklemektir (C: 51, 52, 57). Şair, bir "pembe akşam, altın 1şıklı gündüz”, mazide kalmış gönül sarayı aşk yuvası bir ev, gökyüzüne bakmayı, kısacası "bahtiyarlık" arzulamaktadır. Allah'ın denizine doymayı; "Deniz rüzgârına, pırıl pırıl engine.", “denizlerde yol almaya”, bir çınar gölgesinde yaşamaya doymayı arzulamaktadir (C: 123, 130, 155).

“Dilek” şiirinde Saba'nın arzusu memuru terfi etmiş, öğrenciyi sınıf geçmiş hâlde görmektir. Bahar gününde dertliyi, ümitsizi, herkesi "Mesut olmuş görmek”tir. Şairin "İnsanlar, Bu Güzel Günde" başlıklı şiirde arzuladıkları ise denizde balık, mavi gökte kuş olmaktır. "Çocuk Gülüşleri”nde gülen bir anne ve yuvaya dönen bir baba ile yaşamaktır. "Sabah, güneşe; akşam damdaki aya," gülmektir. "Kavgam” şiirinde arzulanan, ta uzakta haykıran denizdir (C: 95, 159, 160, 173).

Ziya Osman'ın şiirlerinin merkezinde yer alan belli başlı zaman mahfazaları (kronotoplar) "sandık, dolap, çekmece, bahçe, köşe, kapı, eşiği, ev-oda" olarak tespit edilmiştir (Tek, 2013: 2602). Fotoğraf kareleri, resimler de şiirlerdeki zaman mahfazaları olarak ele alınabilir. Saba, "Büyülü Resim”de içinde yemyeşil kırlar, her zaman güzel karısı ve çocuğu bulunan bir resme "gelecek günler" diye bakar. Bu resim karesi, mazi ile âtiyi birleştir. "Eski Odalarda" başlıklı şiirde mazideki oda, emellerin dolup taştığı, ümitlerin söndügüu, şairin gönlüne bir mabet olarak kalan bir virane odadır (C: 31,96 , 
184). Şair, tekerleme üslubuyla kaleme alınmış olan "Çocukluğum”da giden günlerin geri gelmeyecek olmasına hayıflanır. Şiirde mutlulukla özdeş olan çocukluk dönemi özlemle anılır. Şiirde, çocukluk günlerini güzel yapan unsurlar, bütünüyle güzel bir memleket ve bahçelerdir. O yıllar, ölümlü hatıralarla anıldığında ise "sonsuz keder" olur. Sonuçta şair için "habersiz ölen kardeşi, mezarı bilinmeyen eşi”" sonsuz bir hasret kaynağı olmuştur. "Çocukluğum, çocukluğum... / Bir çekmede unutulmuş, Senelerle rengi solmuş, Bir tek resim çocukluğum...” diyen şair, zamanı kaydeden bir fotoğraf karesine dikkat çeker. "Eski Resimler"de de bir fotoğraf karesine yansımış mazi anılır. Duvardaki çerçeveli resimde "Gülümser ölüler,"; çocuklar ellerinde ekseriya bir çember, daha koşmak isterken öylece kalakalmıştır. Fotoğraftaki annenin yeni gelin olduğu da gözlerinden belli olmaktadır (C: 25, 143). "Bir Kapı" şiirinde de gece, maziye ait eşyaları hatıralarıyla saklayıp geleceğe taşıyan sandıklara benzetilir (C: 68).

\section{Kaçış ‘O Belde’ ve Sükût}

Ziya Osman Saba'nın şiirlerinde maziyi andıkça hissedilen hüzün neticesinde dile getirilen arzulardan birisi de bir insana, ölüme veya sükûnetli o belde'lere kaçıştır. Saba'yı temelde hüzünlendiren nedenler ise saadet dolu, ruha denk günlerin "daha gelmeden" geçmesidir. Her an ömrün tükenmesidir.

Hüzün duygusu, "Kışa Girerken” şiirinde sonbahar mevsimi tasvirleriyle izleğe dönüştürülür. Şairin duyuşunda sonbahar, ağaçlarda yaprak yaprak ağlamakta; ölen günle basamakta durmaktadır. Sonbaharda, şairin ıstırabı, ruhuna ferah veren bir rüzgâr olacaktır. Şair, öpemediği anne, bulamadığı kardeş ve uzak ümitlerin hasretiyle hüzne kapıldıkça hayatı; ömrü boyunca kendisine sunulan bir keder olarak niteler. Mazideki mektep karyolasında sessiz ağlayan bir çocuğu ve akşamları içini dolduran mahzunluğu hatırlar (C: 51, 63, 80).

"Kaçış”, şairin hayata karşı almayı tasarladığı tavırlardan birisidir. "Artık Yaşamak İçin" şiirinde biz zamirini kullanan şair, herkesten kaçacaklarını söyler. Ümitli sabahların hasreti içindeki şair, dünyanın en güzel yerine kaçmak niyetindedir. Sükûn dolu akşam gezmeleri, kol kola edebî bir sahilde, yeniden tadılacaktır. "Kanat" şiirinde "Gideyim bırak beni" diyen şairin kaçışı hayattandır. Şairin kaçış için hayal ettiği araçlar ise "Tren, gemi, kanat..."tır (C: 21, 53).

“Bu Vakitsiz Giden Yaz”da ölümün tabiattaki başlangıç yansımaları “dökülen yaprak, solgun bahçe, yaralı kuşlar, sararmış beniz, vefasız leyleklerin akını; elden giden çardak altları, üzüm tadı; ihtiyar çam, selvilerin saltanatı, harap olmuş bahçeler, eylül ayı"dır. Şiirin sonunda da "Karanlıktan, geceden, ölümden korkan gönlün.” denilerek kaçınılmaz son hatırlatılır. Şairin kaçış arzusu "eşiyle ve yazla birlikte, uzak palmiyelere doğrudur. "Gitmek" şiirinde kaçış, şairin kalbini ince ince çağıran bir melteme, denizkızlarının sonsuz ufuklardan gelen şarkıları eşliğinde görülür gibi olan "Bir uzak sisin içinde”, “...yorgun / Mercan adalarının yeşil kıyıları"na doğrudur (C: 72, 77).

"Yaşamak Bundan Sonra"da şairin kaçışı, hatıralaradır. Artık katlanılmaz eziyetten ibaret olan bu hayatı yaşamak istemeyen şair, hatıralardan, kendisini kaybolmuş baharına 
götürmesini, hafızasının kendisini avutmasını ister. Onun bir sığınağı da "beni kurtar ey..." diye seslendiği "şiir"in kendisidir. Şairin kaçışı "Doymak" şiirinde denizlere, deniz rüzgârına, pırıl pırıl engine, çınar gölgesinde dalınacak bir rüyayadır (C: 84, 155).

Ölüm ve ölümün kardeşi olarak nitelenen uyku, Saba'nın şiirlerinde kaçış için düşünülen diğer unsurlardır. "Akşam” şiirinde akşamı içinde bir korku, pişmanlık, hile gibi hisseden şair, teneşirde bir ölü gibi yıkanmayı; arzuları, hırsı, şehveti, kini yıkamayı; yepyeni ve tertemiz bir sabaha uyanmayı arzular. Şair, sırtına uykuyu çekip, gördüğünü görmemek, mutlak manada "Beyin, göz, kulak, / Uyumak" istemektedir. "Uyku” şiirinde de şairin gözleri "Artık ne bir dost sesi ne de bir düşman yüzü” aramaktadır. O, sadece bir mezar toprağını aramaktadır. Soğuktan titreyen bu toprağın öksüzünü, sırtlarına uykuyu beraberce çekmeye davet eder (C: 85, 154, 187).

Sükût, suskunluk, sessizlik hâllerine Saba, pek çok şiirinde yer vermektedir. Sükût hâline de bazen sevinç bazen hüzün duygusu eşlik etmektedir. Kaçışın ve sığınışın zaman dilimlerinden olan geceler, şair için doyulmadık sükûn dolu vakitlerdir. Sessizlik, aynı adı taşıyan şiirde, Saba'nın her şeyin uzakta ve silik olduğu maziden hatırladığı, içindeki bir aşktır. Şair, sessizlikte, başka hiçbir şey duymadan, yalnız sevgilinin aşkıyla, göğsü dolu bir yelken gibi genişleyerek, sevgilinin bir içimlik, bir su gibi ellerini hayal etmektedir (C: 50, 64).

Saba, "Oda" şiirinde muhatabına "Kapıyı sen kilitle, sen yanı başımda kal!", "Beraber dinleyelim sustuğunu gündüzün.”, “..., sus, ...” diye seslenir. Şairin dikkati bir su sesine, bir saate, çinkoda tıkırtılara yönelir. Şairin kalbi, saçaklardaki kuşlardan gelen hüzne kapilır (C: 65).

“Akşam” şiirinde sema sessiz ve alçaktır. Şairin odası, daima gürültüsüz ve sıcaktır. Hayretini "Bugün her şey mi sustu, yoksa ben miyim sağır?" dizesiyle dile getiren şair, muazzam sükûtu yıkmak için güneşi bir çan gibi sallayacak bir kol hayal eder (C: 70).

Hatıraların yaşattığı hüzün neticesinde, sükûta sığınış arzusu, 'o belde'lere dönüşür. Saba'nın özlemini çektiği ve kendisini âdeta çağıran 'o belde', "Davetler" şiirinde ölülerinin yaşadı̆̆ı memlekettir. 'O belde', bir "Bitmez davet,"tir; "Gecenin çağrısı”, ruha "Gel!" diyen sonsuz denizlerin sesidir. 'O belde', zamanın çemberinin dışında, "her şeyin ötesi” bir mekândır (C: 60).

"Bir Yer Bilirim” şiirinin 'o belde'si, ormanlar içinde yeşil bir yerdir. Orada bütün gün gök mavidir. Orada akşam esen bir rüzgâr vardır. Orası, herkesin kendi işinde olduğu, dedikodusuz bir köydür. Sevgilinin kapısını açtığı küçük bir evdir. Orada arılar kovanlarda, köpek kulübesindedir. Şair, orada yaşamayı ve ölmeyi "bahtiyar" sevecektir (C: 78).

"Denizler Aşırı" şiirinde "Götürün atın beni bambaşka limanlara" diyen şair, dünyaya; Avrupa, Amerika, Asya, Avustralya gibi uzak iklimlere yelken açmayı arzulamaktadır (C: 118). "Deniz Kıyısındaki Kulübe” şiirinin hayalî ‘o belde’si özlemle anılır. Şair aile, ev ve tabiatla bütünleşmiş, deniz kıyısında, barış içinde bir kulübe kurmayı düşlemektedir. Bazı şiirlerinde ölümden sonrasını Cennet olarak düşleyen şair, 
benzer güzelliklere sahip bir Cenneti, bu dünyada arzulamaktadır. 'O belde', denizden yana olacaktır. Orada pırıl pırıl enginlerinden geçecek bir gemi, başını sokacak bir kovuk, bütün gün gökyüzünde Tanrısal güneş, akşamları gurup, sabahları güneş bulunacaktır. Orada günler ya serin ya sıcak olacaktır. Şairin düşlediği bu mekânın değerler ve duydu yönleri de şiirde tasvir edilir. Orada dalgalar kıyıya "kardeş kardeş" barış bırakacaktır. Orada "ne kin, ne garez, ne hır, ne tamah" bulunacaktır. Şairin kalbi de orada bir mutluluk içinde aydınlık ve ferah çarpacaktır (C: 120).

Bir diğer 'o belde'de "rüzgâr esmez", adeta "Mesut olun, yaşayın, / ana baba evlat torun..." diye konuşur (C: 121). Ziya Osman'ın o "Hayal Ülke”sinde ayrıca "Ata"sı ve kardeşi Cahit Sitkı da bulunmaktadır. 1938 tarihli "O’nsuz” başlıklı şiirinde Saba, "Bizler ki sıkılsak, 'O başımızda,' derdik” mısrasıyla Atatürk'ün ölümünden duyduğu üzüntüyü dile getirir; ana-baba değil, “Ata öksüzü” kaldık der (C: 44).

1957 tarihli “Düşümde” başlıklı şiir, Cahit Sıtkı Tarancı'nın ölümünden bir yıl sonrasına aittir. Cahit Sıtkı, vaktiyle Ziya Osman Saba’ya kendisine, başını bütün kaza ve belalardan koruyacak bir eşle yapacağı mutlu evlilik hayalleri içinde, duyulmamış şiirler yazacağını söylemiştir (Tarancı, 2016: 235). Cahit Sıtkı'yı rüyasında gören Saba, bu şiirde "Yolumu gözler." dediği arkadaşına duyduğu sevgiyi "Cahit bu, dayanamadı, boynuma atıldı. /Gözyaşlarını duydum yüzümde bir ara. /O, düşümde ağladı, /Bense uyandıktan sonra." misralarıyla dile getirmiştir (C: 142).

Ziya Osman Saba'nın şiirlerinde koyun, bulut, kar, giysi, minare, ev gibi varlıklar dolayısıyla kendisine en fazla yer verilen renk, sükûtun da karşılığı olan beyazdır. Beyaz sevginin, mutluluğun, umudun, saflığın, huzurun, sağlığın rengidir. Saba, "Beyaz" başlıklı şiirde okurlarına "Artık bütün renklerden, artık uzaklaşmalı / Beyaz, işte aylardır gözümde tüten beyaz.” diye seslenir. Açık kalmış bir musluk, okurun muhayyilesinde beyaz rengi canlandıracak şekilde, mermeriyle konuşmakta; kiraz, tek tük beyaz çiçeklerini düşürmektedir (C: 73).

\section{III. Şiirlerinde Düşünce Dünyası}

\section{A. Tabiat, Şehir ve Aile}

Ziya Osman Saba'nın "hep kendi hayatı" olarak nitelendirilmiş şiirleri "özümseme, yaşantıya geçirme, tecrübeyle içselleştirme" (Çetin, 2001: 249) durumları gözlemlenebilen büyük ve anlaşılır şiirlerdendir. Saba'nın şiirlerinde, gönülden bağlı olduğu, çocukluk ve gençlik hatralarıyla bütünleşerek özel bir anlam kazanan İstanbul'u, hem edebî hem de sosyal malzeme olarak yansıttığı; şiirlerinde az da olsa şehirle musikinin bir arada bulunduğu vurgulanmıştır (Tuna, 2020: 191-193). Ev ve aile şiirleriyle öne çıkarılan Saba, metinlerinin hep aynı mevzular etrafında oluşmasından şikâyetçi olan eşinin anlatımlarına göre evinde pek de konuşmayan birisidir. O, ancak kendisine sorulunca, o da kısaca cevaplar veren bir kişiliğe sahiptir. Yine eşine göre bir hikâyeci olarak tanınmak istemeyen Saba, pek çok şiirinde anne-babasının yanı sıra eşinden, evinden, çocuklarından söz etmiştir (Uysal, 2004: 269, 270). 
Ziya Osman, şiirlerinde tabiat, şehir, aile konularını genellikle teşbih-teşhis sanatlarına dayalı imgeler eşliğinde iç içe ele almıştır. "Yükselen Ay" şiirinde şairin hayal dünyasında ay, şehrin üstünde yükselirken bir yarasa, karanlık sokaklara karışır. Dağlar, bir keçi sırtı gibi kabarır. Aç köpekler, ayı selamlar. İnsanları yatışan şehir, gecelerin sisinde kaybolur. "Gece, Ay ve Köpekler”de ay, insanlar gibi, doğmayacak güneşi bekler. Alay alay köpekler, insanların azap kardeşleri olur (C: 46-48).

“İyi Sabah” şiirinde ilkbahar, şairin kapısını çalar. Şairin kalbi, özlenen kişinin hasretine sessizce kavuşur. Gün, henüz kirlenmemiştir. Mevsim, ümitlidir. Tanıdık kuşlar, sevinçlerini paylaşır. "Yaz Öğlesi”" şiirinde kuş, konuşmaktan yorulmuş, susmuştur. "Akşam" şiirinde beygir, dilsiz bakıp susar. Koyun, dert yanmak ister gibi ağıla girer. Dünya, sanki büyük bir gam altında susar. Akşam, yanmış bir tavan gibi çöker. Kargalar, haykırarak kaçışır. "Sönen Gözler”de uzaklaşan gözlerin yerlerinde, yıldızlar güler. Rüzgârda, yalvarışa benzeyen sesler vardır (C: 55, 56, 84, 175).

“İstanbul” Beşiktaş, Küçüksu, Eyüpsultan, Çengelköy, Rumelihisarı semtleriyle şair için aynı zamanda kendi geçmişi demektir. Çocukluğu, gençliği, okuduğu mektep ve evlendirme dairesidir. Açık kollarıyla Boğaz'dır. İstanbul, üstündeki göğü, ciğerlerindeki hava, öpüp başına koymak istediği her taşıyla onun hatıralar şehridir (C: 116).

Bir İstanbul âşığı olan Ziya Osman Saba'nın şiirleri üzerinde söz söyleyenler onun şiirlerindeki "tematik bütünlük, temiz dil, sevgi, geleneğe bağlılık" hususlarına dikkat çekmiş; onun şiirlerinde kültürel art alana ilişkin özelliklerin yanı sıra "gündelik yaşama ait” izler bulunduğunu; "yoksul yaşamlara karşı duyulan utanç, acıma duygusu”na yer verildiğini; "eski evlerin içindeki aile huzurunu, çevresindeki sıcak komşuluk ilişkilerini ve manevî duyguları yitirmemiş semtleriyle İstanbul'u idealize ettiği’"ni vurgulamışlardır (Toklu, 2003: 85; Necatigil, 1985: 285; Demirel, 2007: 110).

Saba, "Garip İstanbul'un Türküsü”nde yoksulluk konusuna şehrin "Fakir fukarası, dulu, yetimi," duvar dibinde el açan insanları aracığıyla; kucağında çocuğu dudağındaki yalvarması ninniye dönüşen bir anneyle, "Gün görmemiş insanlar"1yla, "Susanlar"1yla yer vermiştir (C: 152). Şehirdeki farklı insan tiplerini "Eller" şiirinde deyimler, ad aktarmaları eşliğinde tasvir eden şair; sosyal statüler, meslekler, ruh hâlleri ve karakterleri "insan elleri” aracılığıyla imgelere dönüştürür. Çaresizleri simgeleyen eller, dizlerinin üstündedir. Kimi umursamazların elleri, göbeklerinin üstündedir. Çamaşır yıkamaktan derileri soyulan, avuç içleri nasırlaşmış eller, çalışanları temsil eder. Dilencinin eli, kapanmamacasına açılmıştır. Mahkûm elleri, demir parmaklıklara sarılmıştır. Kimi eller de Allah'a açılmıştır (C: 148).

Şiirlerinde Cahit Sıtkı'nın etkisi de gözlemlenebilen Saba, zamanla kendi şiir tarzını oluşturmuştur. İlk şiirlerinden itibaren şair, yüce değerlerle özdeşleştirdiği geçmiş ve geçmişte kalanlara dönük özlem duygusunu dile getirmiş; ilhamının çıkış odağ 1 da genellikle ailesi, yakın çevresi ve sevdikleri olmuştur. Ziya Osman; anne, baba ve eş figürlerine de genellikle ya kendi çocukluğunu hatırlarken ya da kendi çocukları ile ilgili hayaller kurarken yer vermiştir. "Çocukluğum" başlıklı şiirinde şair için 
çocukluk dönemi, “uzakta kalan bahçeler, gelmez günler, sabahlar, geceler”dir. Gözünde tüten memleket, sonsuz hasret ve kederdir. Habersiz ölen kardeşi, mezarı bilinmeyen eşi, her şeyidir. Çocukluğu, "Bir çekmede unutulmuş, / Senelerle rengi solmuş, / Bir tek resim..."dir (C: 25).

Cahit Sıtkı Tarancı'ya ithaf edilen “İmkânsız Tesadüfler” başlıklı şiirde, Saba’nın mektebe gitmek için kullandığı yol, kendisine "Ziya!" diye seslenen babasını hatırlatır. Bu yol kalbindeki eski sevinçleri ve dallardaki eski baharları özlemle hatırlatır. Koluna girecek melek gibi karısını, doğmamış çocuklarını hayalinde canlandırır (C: 28).

Saba, aile bireylerine hem mazide kalmış mutluluk sahneleri dolayısıyla yer verir hem de ânda yaşattıkları duygular hatta gelecekteki, öte âlemdeki olası birliktelikleri dolayısıyla yer verir. "Açmak İstersen Eğer" başlıklı şiirde şair, kül olmuş vücutları ruhuyla dirilten özlenenin "Bir sabah ellerini son defa öpmek için, / Zayıf parmaklarında günleri” saymaktadır (C: 66).

"Bir Kapı" şiirinde bir gece vakti kendi gönlüne seslenen şair, naftalin kokan beyaz serin bir geceliği ve o geceliği tenine giydirecek annesinin ellerini düşler. "Evlilik" şiirinde eş, "Birlikte bütün ömür; mesut yaz, tasalı kış." geçirilen kişidir. Eş, Allah'ın bir sabah karşısına çıkardığı, ondan ayrı düşünce ayrılığı anladığı, bazen anne diye dizlerine yattığı kişidir. Ailenin barındığg ev, “Gönül sarayı, aşk yuvası...”dır (C: 68, 89, 126).

Saba, annelikteki güçlü sahiplenme duygusunu da "Ana, Baba, Evlat" adlı şiirinde yer verir. Yavrusunu bağrına basan anne " 'Onu ben doğurdum, ninnisini söylüyorum. /Allah'ın bile değil! /O yalnız benim yavrum..., " der. (C: 90).

\section{B. Allah, Teslimiyet ve Kendini Bilme}

Mehmet Kaplan’a göre Ziya Osman Saba, "Hayat ve eserleriyle uçak veya fabrika gürültüsü çıkaran Nazım Hikmet tipinde meydan veya sahne şiirlerinin” tam zıttı, hayatında olduğu gibi şiirinde de sesini fazla çıkarmayan ve son derece mütevazı bir kişilik yapısı sergilemiştir. Onun şiirinde Cahit Sıtkı ve Orhan Veli'dekine benzeyen bir "kendine yetiş, hayatın manasını ve saadeti yaşanılan hayatın teferruatında arayış ve buluş" vardır (Kaplan, 2008: 383).

Ziya Osman, pek çok şiirinde Allah'a seslenir, Allah’tan yardım diler. Bir “yol şiir”i olan "Her Akşamki Yolumda" şiirde mutlak huzura ve sükûnete kavuşma arzusu, kaçış düşüncesine, sığınma arzusuna dönüşür. Şikâyet hâlindeki şair, "Sen, bana en son kalan, ben senin en son kulun; / Bu akşam, artık seni anmayan İstanbul'un / Bomboş bir camiinde uyumak istiyorum." diyerek kaçış isteğinin gerekçesini ortaya koyar. Şair, “Tanrı'yı unutuş"tan mustariptir ve temel izlek olarak mutlak huzurun, sükûnetin Tanrı’ya sığınmakta olduğu düşüncesine varmıştır. Bu şiirde sığınma yolculuğunun menzilleri ise ev, cami, ölüm ve Tanrı'dan oluşmaktadır. Şair, (cami) taşlığı, bir döşek kadar ılık olan Rabb'inden, kutsal metinlerde de adları geçen zeytin ve ekmeği ister. Rabb'ine "az daha yakın yaşamak için" , İlahî âlemin "sonsuz sessizliğini dinlemek" ister (C: 38). 
Minareleri, semaya açılmış kuyulara benzeten Saba'ya göre bütün olaylar Allah içindir ve onun sahipliğinde gerçekleşir. Gögün kararması, "Geçip gidişi ömrün”; dal, ağaç, yaprakların dökülüşü hep Allah içindir. Allah tabiatı, insanları düzene sokandır. Güneşi bir nur olarak yüzlere dökendir. Allah, hasret kavuşturan, gözyaşı dindirendir. "Benim ne karım ne de çocuklarım var, / Mademki bu dünyada her şey / Bir kere göz kapanıncaya kadar..." diyen şair için Allah, her şeyin sahibidir, malikidir (C: 36, 45, 124, 128).

“Gün” şiirinde “-Ya Rab! Nihayet günümüz gün olacak.” diyen şair, gelecek iyi günlere dair beklentilerini dile getirir. Beklenen günlerde gönüller hoş, mevsim güzeldir. O günlerde, kenarında evler kurulu ırmaklar, biteviye akmaktadır. Şair, "Belki de hurilerle düğün olacak..." misrasıly ümitlerine Cennet'i katar (C: 59).

"Bu Vakitsiz Giden Yaz" başlıklı şiire, ümitsizlik ve karamsarlık duyguları hâkimdir. Şair, eşine hitap ederken, ölüm olgusu karşısında salt korku hâli içinde değildir. Şair, vücudu ürperen, gözlerinde eylülün hüznü okunan hayat arkadaşına sığınak olmak istemektedir. Eşine "Karanlıktan, geceden, ölümden korkan gönlün” ile “...vücudunu yavaşça koluma ver.” diye seslenene şair, selvilerin yanı sıra ihtiyar çam ağaçları ile de bu şiirde ölümü hatırlatır. Uzak diyarlara kaçma arzusunu hissettiren şair, kendisi için geliştirdiği, ölüme karşı teslimiyet gösterme fikrini eşine de telkin eder (C: 72).

Saba, tasavvufî literatürdeki hayret makamını/hâlini hatırlatan "Hayret" adlı şiirde görünen âlemin, "Ağaç, dal, yaprak" her şeyin bir mucize olduğunun farkındadır. Sevmede, ölmede ve ömrün devam etmesinde, her işte Allah'ın meramını anlamıştır. Şairin hayreti "Nasıl” şiirinde ise bir yanda düğün varken "Ötede cenaze." olmasınadır; sıra sıra evlere, dükkânlara, mezarlıklaradır. "Kâh kavuşma kâh ayrılık...”laradır. " Ben, böyle oldum işte!" diyen gözleri kapatılmış, çenesi bağlanmış "Bir Ölünün Dedikleri”"nedir. Şairin hayreti, teneşirde uzanmış "mosmor, taş gibi soğuk." ayaklaradır (C: 92, 104-106).

Sonuçta Allah'ın merhametine sığınan şair, toplu şiirlere de ad olan "Cümlemiz"de Allah’tan yolcusu, hancısı, "Şu anda yeraltına günahıyla gömülen.” ölüsü, ölü yıkayıcısı, hastası ve hastabakıcısı ile herkese acımasını diler. Şairin Allah'ın merhametine teslimiyeti, tevekkülü, boyun eğişi “Toprak üstünde yürümek: kabul / Toprak altında çürümek: kabul.” dizelerinde de dile getirilir. (C: 102, 156)

Şair, "Bilemiyorum" şiirinde kendisini, şiir serüvenini, ailesini, ölüm korkusunu, kendi hayatını, topyekûn yaratılış gayesini sorgular. Şairin "Düşünmez misiniz? Akıl etmez misiniz?" türünden İlahî hitaplara cevabı "Düşünürüm, düşünürüm...” olur. Tanrı’ya seslenen Ziya Osman; bilgisizliğini, kavrayışının noksanını ve aczini "Bilemiyorum yıllardır neredeyim? / Her gün yediğim ekmek, susayıp içtiğim su, /Kolundan tutup gitmek istediğim kadın, /Yaşamak kaygısı, gök hasreti, ölüm korkusu, / Ve Rabbim senin adın!" mısralarıyla itiraf eder. Yarını bilemediğini söyleyen şair, havf ve recâ hâlleri arasında gidip gelir. O, Rabb'inin maksadını ve kararını merak etmektedir. Şair, görünen ile öz arasındaki olası farka da "Rabbim! Beni 
yaratmışsın, / İnsan şeklinde görünürüm,” mısrası ile değinir. Ruhun İlahî bir vergi, bedenin ise dünyevî, görünen bir suret olduğu bilincine erişen şair, kendini bilmek yolunun tefekkürden, düşünmekten geçtiği sonucuna varır (C: 18).

"Kurban" şiirinde insanın acziyet durumu, kurban simgesi ile ifade edilir. Ziya Osman'ın Tanrı ile hasbıhal şiirlerinden biri olan “Kurban”da Yunus Emre'yi hatırlatan bir arayış ve kendini buluş söz konusudur. Kurban dini ritüellerin, ibadetlerin nesnesi iken acizliği, iradesizliği ifade ederken söz konusu ritüellerde özne olunduğunda fedakârlığı simgeler. Kurban, yüce bir tasavvufî gaye olarak rıza makamının da bir göstergesidir. Ziya Osman da "Kurban" şiirinde "Kulların arasında ben yaşadım sessizce, / Hiç ağzımı açmadım, verdim bütün yünümü / En geniş bir sabahı düşünerek her gece, / Ben, Tanrım, şuracıkta bekliyorum günümü." diyerek kendisini bir kurbanla özdeşleştirir. Mutlak huzur arayışı, ölüme teslimiyet ve insanî acziyeti, bu kabulle başlar. Şiirde "en geniş sabah"a vuslatla nihayete erecek olan teslimiyet süreci, kurtuluş ve Cennet getirecektir (C: 35).

Tanrı'ya hitabın bir üslup özelliği olarak öne çıktığ “Geç Kaldık” adlı şiirde, ölüm olgusu karşısında geç kalmışlığın yarattığı pişmanlık dile getirilir. Şaire göre hayatın hedefi sükûna ermektir. Ölüme de hazırlıksız yakalanılmamalıdır. Dünya meşguliyetlerinin kendisini oyalamasından yakınan şair, "geç kaldık" sözünü pişmanlık duygusuyla beş kez tekrar eder. Şair, ne yapılmalıydı, sorusunun cevabını ise doğrudan vermez. Şiirde, mutasavvıfların ölüme her an hazırlıklı olmayı salık veren "Ölmeden önce, ölünüz." rivayetine, hesap vermeye geç kalmak" biçiminde göndermede bulunulur (C: 58).

Dinî metinlerde canlı cansız bütün varlıkların Tanrı'ya itaat ettiğinden, Tanrı'yı kendi lisanları ile zikrettiğinden söz edilir. İtaat eder gözükmese bile Tanrı'nın koyduğu tabiat kurallarına bağlı oluşu yönüyle, kendini irade sahibi bilen insan için dahi sonuçta itaat kaçınılmaz görülür. "Rabbim, Nihayet Sana" adlı şiirinde de Saba, "Ben artık korkmuyorum, her şeyde bir hikmet var” derken ölümün güzel yüzünü, bir bahçeyi müjdeliyor olmasında bulur. Öyle bir bahçe ki içinde sevgilisi ve annesi vardır. "...çok şükür öleceğiz...” diyen şair, ölüm olgusu karşısında ümit içindedir (C: 37).

\section{Hayat, Ölüm ve Öte Âlem}

Saba'nın şiirlerini kronolojik açıdan inceleyen Sami Akbulut, şairin sırasıyla "değişken ve karmaşık muhtevalı ve çoklukla da melankolik şiirler", "geçmişe sı̆̆ınış eksenli şiirler", "uzaklara gitme arzusuna ve ölüme dönük şiirler”, "geçmişe özlem/çocukluk hatıraları konulu şiirler" ve son olarak "ölüm temi ağırlıklı şiirler" kaleme aldığ 1 tespitinde bulunur (Akbulut, 2008: 129).

Hayat ve ölümün iç içeliğini bütün benliğiyle duymak isteyen Saba, "Toprağım" şiirinde, kumruların "Hu.." sesinden içine ahiretin dolmasını temenni eder. "Şu musalla taşında bir namaz yatacağım.” diyen şair, toprağının da gözlerine yakın olmasını diler. Şairin ölüm gerçeği karşısındaki duyuşunda ömür, uzun kısa "Kısmet ne kadarsa.", "Birkaç bahar" be "bir o kadar kış."tır. Hayat, "Ölmüşlerin izinde" bir tür "yeniden başlayış"tır. "Promete" şiirinde ise bir işkencedir. Şair, bu işkenceye diz bükmeden, 
simsiyah bir boşluğa derdini “inler”. İnsan, tasında su yerine kum bulunan bir varlıktır. İnsan hayatı, bir avuntu için her yalana kanmaktır. İnsanın ölümü, on iki şerefeli uzun minarelerden verilecek son bir selamdır. Şairin duyuşunda kader ise bir gizem olmakla birlikte apaşikârdır. Belki dışımızda, belki içimizdedir (C: 39, 45, 93, 141, 145, 172).

Ziya Osman, pek çok şiirinde ölüm gerçeğini sorgular. "Ölüler” şiirinde ölülerin gittikleri yer, artık bir bilinmezdir. Ölülerin artık gündüzleri gece, bütün günleri dün, her sözleri sükût, her işaretleri gizlidir. Bu tasvirlerde şairin ölümü yokluk olarak görmek istememesi dikkat çeker. Şair için ölüm, kaybedilmiş yakınlar demektir. Şair, ne zaman aynaya baksa babasını, bahçesini, odasını, evlerinin sofasını hatırlar. Her yerde onlardan bir eser görür. Şairin ruhunun dinginliğe kavuşması, muradına ermesi de bir açıdan sevdiklerinin gittiği bir yerin varlığına inanmasına bağlıdır. "Ahret” adlı şiirde ölümü kendisine uzanan ele, anneye ve diğer sevenlere erişmek üzere geçilmesi gereken bir eşiğe benzeten şair için ölüm, "bir yükü atmış gibi” içinde hissettiği bir hafifliktir. Şair, "Bu garip dünyada ben yadırgadım yerimi..." demekle kendini mazide kalmış insanlara daha da yakınlaştırır (C: 27, 34).

Ölüm konusunun işlendiği şiirlerden "Rabbim, Nihayet Sana", Cahit Sitk1 Tarancı'nın "Memleket İsterim” başlıklı şiirini hatıra getirir. "Artık ne kin, ne haset, ne de yaşamak hırsı, / Belki bir sabah vakti, belki gece yarısı, / Artık nefes almayı bırakıp gideceğiz..." diyen Saba, bu şiirinde ölümün kaçınılmazlığını ve vakitsizliğini hatırlatır. Ölmekle, sonuçta insanın Rabb'ine itaat edeceğini söyler (C: 37).

Ölüm düşüncesi, ölmüş akrabalara duyulan özlem ve yaşanılan dünyaya yabancılaşma durumu "Kuyular" şiirinde de izleğe dönüştürülür. Şiirlerde ölüm bahsi, genel olarak bir son, yeni bir başlangıç, yokluk veya dertlerin son bulması gibi yönleriyle öne çıkarılırken Ziya Osman, bu şiirinde ölümü, kavuşturma yönüyle dikkatlere sunulur. Şair, ölmüş aile bireylerini özlemektedir. Onlarla tekrar irtibat sağlayacak yegâne vasita ölümdür. Bu hususta dirilerden de bir hayır gelmemekte ve ölümün sesi bir "nağme" olmaktadır. Ölüm, sular tarafından çekilen şairin kalbini, yavaş yavaş avucuna almaktadır. Ölüm, ona tuzak olan mehtaplı kuyularda şarkı söylemektedir. "Bütün insanlar" dediği diriler, artık ona yabancıdır; 1raktır. Şair, ölüleri de kendisine çok yakın duymaktadır (C: 71).

Ölüm, “Toprak” şiirinde sükûtu korkularak dinlenen bir olgudur. Ölüm, hatıra geldiği zaman, topraktaki bir yılanın mezarlarda kışın 1lık, yazın serin olduğunu tekrar ettiği bir hakikattir. Ölüm, Tanrı'nın insanları yanına çağırmasıdır, "bir yaprak dökümüdür dört yandan.”, şairin vücudunu “yatakta bekleyen ecel”dir (C: 79, 144, 155, 169).

Ziya Osman, Hamlet’in elinde kafatasıyla yer aldığı sahneyi çağrıştıran "Ne Dertler Çektin Başım" adlı şiirinde, "O gün ilk iş olarak mezarıma eğilip, /Kalan kemiklerimi bir bir toplayacağım. / O hayata yepyeni bir vücutla dirilip, / Zavallı kafatasım, seni okşayacağım.” mısralarıyla ölümün belki yemyeşil bir rüya gibi geçeceğini, belki ölümün sonunda uyanılabileceğini söyler (C: 81).

"Her Sabah Uyanınca" şiirinin konuları, ölüm ve Cennet arzusudur. Şair, "Beklemekteyiz, Rabbim, sonunu ömrümüzün. / Yarımız burada kaldı, gitti gelmez 
yarımız." mısralarıyla çaresizliğini ve iradesizliğini, ölmüş olan sevdiklerine duyduğu özlemi, teslimiyet duygusu içinde dile getirir. Ölüm, şair için korkulacak veya şikâyet edilecek bir konu değildir. Çünkü ölüm sonrası arzulanan Cennet, kaybedilmiş sevilenlere kavuşmak için "Hiçbir şey yok olmamış, her şey yerli yerinde," bir duraktır. $\mathrm{Bu}$ şiirin izleği, ölümün yokluk olmayıp ancak vuslat olduğudur. Yaşama arzusu, sonsuzluk özlemi, gençlik özlemi, tabiat özlemi, sevilenler hep bir bahçede; herkesin orada genç olacağı rivayet edilen Cennet bahçesindedir. Şair, Tanrı'ya sesleniş üslubuna bu şiirinde de yer verir (C: 83).

Ölüleri, mezarında "rahata varmış" kişiler olarak gören şair, "Geri vereceğiz hepsini... / Bunca y1llık vücudumuz; el, kol, ayak, / Öpüştüğümüz dudak; / Yeşilini gözlerimizin, mavisini." derken, ölüm karşısında korkulu bir ruh hâline kapılır. Çünkü sonuçta, genç yaşı bütün vücutlar bir tabutun içinden toprağa karışacaktır (C: 114, 133).

“Sefer Hâli” şiirinde ölüm, günü dolmaktır. Dört kollu bir tabutun yola koyulmasıdır. "Kısmet kiminse... Zengininden, fikarasından, / Bir garip kişi veya bir ünlü, / Kim olsa üzgündür üzgün gönlü, / Son defa geçerken yaşayanlar arasından.”diyen şair, bakışını ölen kişiye yönelttiğinde ölüdeki hüzne de odaklanır (C: 134).

Şair, kendisi için söz konusu olunca ölümü, herkesi bırakıp gitmek olarak niteler. Şair için tanıdık ölüler, oturduğu evde oturmuş; ayak sesleri, el izleri, göz nurları, kokuları, yattığı şilteye sinmiş kişilerdir. Onların hayatları, duvarlardaki resimlerde yaşanmıştır. Dört bir yanda ölülerin sükûtları hissedilmektedir (C: 135, 136).

Ziya Osman'ın Cehennem, ceza, hesap günü ve haksızlık gibi düşünceleri içermeyen metafizik / mistik duyuşunda ölüler, bazen de kayıtsızlık duygusu içinde ele alınır. "Ölülere ne gökyüzünün mavisinden" diyen şairin o anki duyuşunda ölüler; gözlerini kör, kulaklarını sağır etmişlerdir. Ölüler, "Sırt çevirmişler her şeye, dünyaya küskün”dürler. Güneşin doğup doğmaması onların umurlarında değildir (C: 137).

Saba, , "Mezarcı" adlı şiirinde ölümü mezarcı motifiyle ele alır. Onların yaptığı işi de “Adem'in toprağını kürek kürek dökmek; şen delikanlıların, solgun nişanlıların kabrine terlerini silerek tükürmek” biçiminde tasvir eder (C: 178).

Şair, “Günün Ölümü” şiirinde ölüm olgusunu zamana teşmil eder. Cenaze evindeki uğultu, yeri sarar. Bir kefen, solgun ufuklar devşirir. Akşamın tahtaları çatlamış loş tabutu, ölen günün üstüne ağır ağır iner. Boğuk rüzgâr, son bir hıçkırık gibi yükselir. Günün tabutu, gecenin kollarına iner. Bir mezar, derin karanlıklarda kapanır. (C: 182, 183)

Ziya Osman, hep gözlerimin önünde dediği "Beyaz Ev"de bütün bir ömür bırakmayacağı eli, okşayacağı saçı, dinleyeceği sesi, bakmakla doymayacağı yüzü hayal eder. Şair, hayatta olduğu gibi ölümlerinde de sevilenlerle beraber olmayı düşler. Yeniden dirilişte anne-babalarla, o beyaz evde tekrar bir arda bulunmayı arzular. "Bir Ölünün Arkasından" şiirinde bahsi geçen ölüyü, az daha yaşatmak istediğini söyler. Ölümü ve ölümden sonrasını, tekrar dirilmeyi hatırlatan şair, aile hasretini giderme 
ümidini öte hayata erteler. Orada tekrar aynı sofrada oturmak ihtimalini dillendirir (C: 22, 26).

Şairin duyuşunda ahiret, saadetler bütünüdür. Bahtsızların biraz gülümsemesi, körlerin gün görmesidir. Ana, baba, evlat bütün kaybolanların "Ebedi bir sabahta" tekrar buluşmasıdır. Şair, o güne kavuşmak için de "Ölüller! Hepimiz için yalvarın Allah'a..." diye seslenir (C: 42 ).

Öte âlem düşüncesi "Merhume" şiirinde yokluk düşüncesiyle birleşir. Şair, biten çocukluğunu, ağlaması dinmeyen selviyi, zaman diye ölünün mezarından geçen mevsimleri düşünür; şiirini "Yokluk, her yanda yokluk. / Toprak olan kemik, boşalan mezar." mısralarıyla sonlandırır. "Göklerde Öten Kuşlar" şiirinde görünmez bahçeye sahip sema, şaire kendisini "ürpermez sükûnu, işkenceli gündüzü, sıtmalı geceleri ve firarda bulutları" ile duyurur (C: 69, 75).

Ölümün korkunç yüzünün en fazla görüldüğü zamanlar, devletlerarası savaşlardır. Saba da o kasvetli zamanların dolaylı bir tanığı olarak 1945-1946 tarihli "Biz, İnsanlar" ve "İnsanlar" adlı şiirlerinde "Ordular: insanlardan... geçtiği yerde ot bitmeyen / Ev bark yıkan, pusu kuran, hak yiyen. / İnsanlar kurt, insanlar fill, insanlar tilki... / Açmayan gül, ötmeyen bülbül, yeşermeyen sevgi." diyerek militarizm eleştirisinde bulunur (C: 98).

Şairin savaş dolayısıyla yakındığı insanlar, "Birbirini yemek için boğuşanlar"lardır. "Dudaklarının ucunda yalanları, / Damarlarında kan, etlerinde şehvet. Kin, garez, hırs, hiddet..." olanlardır. Şairi ürpertenler, kendileri hakkında "Allah'ım! Sen yaratmadın insanları." dedirten kişilerdir (C: 99).

1948 tarihli "Çocuklar Bakıyorlar" şiirinde savaş endişesinin hissedildiği yıllar, "çocuk" bağlamında ele alınır. Oyuncakları, ellerinde tutamayan çocukların bacakları koşamaz olmuştur. Bir şey sormak ister gibi büyüklerin ellerine bakan benizleri sapsarı, o yaşta bedbaht olmuş hasta çocuklar, bir şey sormak ister gibidir (C: 150).

Saba, 1950 tarihli "Patik Yap Kunduracı" şiirinde de çocukların hastalık, gıdasızlık ve verem gibi sıkıntılardan mustarip olmasından yakınır. "Çocukların öldüğünü istemem..." diyen duyarlı şair, tabutçudan ölçüsünü büyük tutmasını ister (C: 151).

\section{IV.Sonuç}

Cumhuriyet Dönemi şairlerinden Ziya Osman Saba, öz şiir-saf şiir anlayışını, sanatının merkezine alarak bu hayattaki güzellikleri ölümsüzleştirip okurlarıyla paylaşmak çabası içinde olmuştur. Saba'nın şiirlerinde ele alıp izleğe dönüştürdüğü belli başlı konular, "merhamet, sevgi, yaşama sevinci; hatıralar, özlemler, arzular; kaçış, 'o belde' ve sükût; tabiat, şehir, aile; Allah, teslimiyet, kendini bilme; hayat, ölüm ve ahiret" olarak srralanabilir.

Kendi şiiri için "garip ve iç dökme" nitelemelerinde bulunan Ziya Osman Saba'nın şiirlerinde gönlü zamanın üç hâlinden daha çok maziye ve geleceğe dönük olmuştur. Mazi, onu hatıralara çekerken âti, hayallere sürüklemiş̧ir. Bu gelgitler içinde şair, Tanrı'ya, hayata, insana, tabiata ve eşyaya yaşama sevinci, sevgi ve merhamet ile 
bakmıştır. İyiliği yücelten, tabiatta sonsuz bir iyilik bulan Saba, kin duygusunu şiir sanatından uzak tutmuş; karamsarlık duygusuna ise pek az yer vermiştir. Şiirlerinde bazı endişe ve korkularına yer vermiş olmakla birlikte saadet ve ümit duyguları ön plana çıkarılmıştır.

Saba, şiirlerinde hatıraları bazen kendisini ezen, ona acı çektiren bazen de mutluluk kaynağı ve hayata bağlayan unsurlar olarak ele almıştır. Şair, hem hâldeki hem de mazideki tanıdıkları ve aile bireylerini derin bir sevgi, iyilik ve özlemle anmıştır. Şairi maziye götüren belli başlı unsurlar fotoğraf kareleri, eski eşyalar ve mekânlar olmuştur. Şairin geleceğe dair düşleri de aile bireylerinden oluşan insanlarla şekillenmiştir. Şair, her insan için başarı ve mutluluk arzulamaktadır. Kaybettiklerini hatırladıkça hâlden kaçmak isteyen şair, "yabancı iklimler, deniz, sükûnet, sevgili” gibi unsurlara sı̆̆ınmak istemektedir. Bazen de bizzat hatıralara, uykuya, cennet misali hayali bir 'o belde'ye hatta ölüme sı̆̆ınmak istemiştir. Saba'nın şiirlerine yansıyan hatıralardaki baba figürü ile de vaktiyle güzel, saadetli anılar yaşandığı görülmektedir. Şair için, anne başı başına sevgi, şefkat ve emniyet kaynağı olmuştur. İstanbul ise çocukluğu, ilk gençliği, evliliği, bütün bir hayatı, ciğerlerindeki hava demektir.

Şiirlerinde, insanın acziyetine dikkat çeken Saba, kader karşısında teslimiyetçi bir ruh hâli sergilemiştir. Ona göre her şey Tanrı'nındır. Her yaşanan Tanrı içindir. Bazı şiirlerinde de gördüğü hikmetleri adeta dervişane bir gönülle hayret hâlinde dile getirmiştir. Onun şiir dünyasında hatıralar, anne, ev, aile ve diğer sevilenler, birer değer olmanın yanı sıra şair için birer liman ve sığınak olmuştur. Hayatı ve ölümü iç içe algılayan şair ölümü, on iki şerefeli uzun minarelerden verilecek son bir selama, kendisine uzanan ele, anneye ve diğer sevenlere erişmek üzere geçilmesi gereken bir eşiğe benzetmiştir. Ona göre ölüm, mesut ölmüşlere kavuşturan bir vasıtadır. Sükûtu korkularak dinlenen Tanrı çağrısıdır. Ölüm, insanın gününün dolmasıdır. Yeniden dirilişe, öte hayata, ebedî sabaha kavuşturan duraktır.

\section{Kaynaklar}

Akbulut, S. (2008). Ziya Osman Saba'nın Şiiri. (Yayımlanmamış Yüksek Lisans Tezi). Yüzüncü Y1l Üniversitesi.

Uygur, S. (2005). Türlerarası İlişkiler Açısından Ziya Osman Saba’nın Şiir ve Öyküleri. (Yayımlanmamış Yüksek Lisans Tezi). Marmara Üniversitesi.

Bek, K. (2004). Şiirden Eleştiriye, Bordo Siyah.

Çetin, N. (2001). Türk Şiirinde Anlam Sorunu, Hece, Türk Şiiri Özel Sayısı 53, 54, 55, 247-262.

Çetin, N. (2009). Şiir Çözümleme Yöntemi, Öncü Kitap.

Demirel, S. (2007). Ziya Osman Saba'nın Şiirinde Ev. (Yayımlanmamış Yüksek Lisans Tezi). Bilkent Üniversitesi.

Enginün, İ. (2001). Cumhuriyet Dönemi Türk Edebiyatı, Dergâh Yayınları. 
İleri, S. (1992). Milliyet Gazetesi, 8.5.1992.

Kaplan, M. (2008). Şiir Tahlilleri 2 Cumhuriyet Devri Türk Şiiri, Dergâh Yayınları.

Kırc1, M. (1991). Ziya Osman Saba Hayatt-Eserleri-Sanatt, Ondokuz Mayıs Üniversitesi Doktora Tezi.

Korkmaz, R.; ÖZCAN, T. (2005). Yeni Türk Edebiyatı El Kitabl, Grafiker Yayınları.

Kudret, İ.; İNCI, H. (1995). Cevdet Kudret'e Mektuplar, Ümit Yayınc1lı.

Kurdakul, Ş. (1973). Şairler ve Yazarlar Sözlüğ̈̈, Bilgi Yayınevi.

Kurdakul, Ş. (2000). Çağdaş Türk Edebiyatı 3, Evrensel Basım Yayım.

Kürüm, E. (2018). Yazarın Niyeti Işı̆̆ında Bir Bağlam Çözümlemesi: 'Mesut İnsanlar Fotoğrafhanesi', Erdem S., 74, 63-78.

Miyasoğlu, M. (1999). Ziya Osman Saba, Akçağ Yayınları.

Necatigil, B. (1985). Edebiyatımızda Eserler Sözlüğü, Varlık Yayınları.

Okay, O. (2005). Batılılaşma Devri Türk Edebiyatı, Dergâh Yayınları.

Saba, Z. O. (2014). Cümlemiz - Bütün Şiirleri, Can Yayınları.

Sakallı, F. (2011). Mesut İnsanlar Fotoğrafhanesi’nden, Değişen İstanbul'a Ziya Osman Saba'nın Hikâyeleri ve Hikâyeciliği, Erdem S., 59, 145-168.

Tarancı, C. S. (2016). Ziya'ya Mektuplar, Can Yayınları.

Tek, Z. (2013). Ziya Osman Saba'nın Şiirlerinin Kronotop Bağlamında İncelenmesi, Turkish Studies, 8(1), 2583-2604.

Toklu, O. (2003). Şiir Dili ve Çevirisi, Akçă̆ Yayınları.

Tuna, H. B. (2020). Ziya Osman Saba, Behçet Necatigil, Bedri Rahmi Eyüboğlu, Orhan Veli Kanık, Necip Fazll Kisakürek ve Attilâ Ilhan'ın Şiirlerinde Şehir. (Yayımlanmamış Yüksek Lisans Tezi). Marmara Üniversitesi.

Uygur, S. (2005). Türlerarası IIlişkiler Açısından Ziya Osman Saba'nın Şiir ve Öyküleri. (Yayımlanmamış Yüksek Lisans Tezi). Marmara Üniversitesi.

Uysal, S. S. (2004). Eşlerine Göre Ediplerimiz, LM Yayıncıllk.

Ünlü, M.; ÖZCAN, Ö. (1988). 20. Yüzyll Türk Edebiyatı 2, İnkilâp Kitabevi.

Yardım, M. N. (2006). Edebiyatçılarımızın Çocukluk Hatıraları, Nesil Yayınları.

Yüksel, B. (2006). Ziya Osman Saba ve Dergilerde Saklı Kalmış Şiirleri, Bilig Türk Dünyast Sosyal Bilimler Dergisi, 38, 15-34. 